\title{
STUDI HYGIENE SANITASI PENGOLAHAN MAKANAN DAN KANDUNGAN Salmonella sp PADA BAKSO YANG DIJUAL DI JALAN JENDERAL SUDIRMAN SOKARAJA TAHUN 2016
}

\author{
Bening Ratri Wiji ${ }^{1)}$, Asep Tata Gunawan ${ }^{2)}$ \\ Jurusan Kesehatan Lingkungan, Politeknik Kesehatan Kemenkes Semarang, \\ Jl. Raya Baturaden KM 12 Purwokerto, Indonesia
}

\begin{abstract}
Abstrak
Kasus keracunan makanan menduduki urutan penyebab kejadian luar biasa (KLB) kedua di Jawa Tengah. Tujuan penelitian ini adalah Mendeskripsikan hygiene sanitasi pengolahan makanan dan kandungan bakteri Salmonella sp pada bakso yang dijual di Jl. Jenderal Sudirman Sokaraja Tahun 2016. Penelitian ini bertujuan mendeskripsikan hygiene sanitasi pengolahan makanan dan kandungan bakteri Salmonella sp pada bakso yang dijual di Jl. Jenderal Sudirman Sokaraja Tahun 2016. Jenis penelitian ini termasuk penelitian deskriptif yang menggambarkan hygiene sanitasi pengolahan makanan dan kandungan Salmonella sp pada bakso. Pengumpulan data diperoleh melalui observasi menggunakan checklist dan pemeriksaan bakso di laboratorium. Hasil hygiene sanitasi pengolahan bakso di 5 pedagang mulai dari penjamah, sanitasi alat, sanitasi tempat pengolahan, penyimpanan bahan makanan, pengolahan bakso, pengangkutan bakso, dan penyajian bakso dikategorikan tidak memenuhi syarat. Sedangkan bahan makanan, pemilihan bahan makanan, dan penyimpanan bakso dikategorikan memenuhi syarat. Berdasarkan pemeriksaan 5 sampel bakso di laboratorium kelima sampel bakso negatif Salmonella sp. Untuk pemeriksaan Angka Lempeng Total (ALT) pada alat makan kelima warung bakso semuanya tidak memenuhi syarat. Kesimpulan hygiene sanitasi pengolahan bakso di 5 pedagang masih ada yang tidak memenuhi syarat, serta dalam 5 sampel bakso negatif Salmonella sp dan Angka Lempeng Total dari 5 warung tidak memenuhi syarat. Saran yang dapat diberikan yaitu sebaiknya pemilik warung memperbaiki hygiene sanitasi pengolahan makanan dan menggunakan 3 bak cuci untuk mencuci alat-alat dapur agar mengurangi angka kuman di alat pengolahan.
\end{abstract}

Kata kunci : Hygiene sanitasi pengolahan makanan, Salmonella sp

\begin{abstract}
Study On Food Processing Hygiene Sanitation And Content Of Salmonella Sp In Meatball Which Sold In Jenderal Sudirman Road Sokaraja Year 2016. Cases of food poisoning is in second rank causes of extraordinary events (KLB) in Central Java. The purpose of this study, is to describe the hygiene sanitation of food processing and content of bacteria Salmonella sp in meatballs which sold in JI. Sudirman Sokaraja 2016. The method used is descriptive that describe management of food hygiene sanitation and Salmonella sp content of meatballs. Data collected through observation use checklist and examination meatballs in laboratory. Based on the result, hygiene sanitary processing of meatballs in five traders, kind of: handlers, sanitation tools, sanitary treatment facilities, storage of food, meatball processing, transporting and serving meatballs, categorized as ineligible. Based on the examination of 5 samples in the laboratory, fifth meatballs samples are negative Salmonella sp. For inspection "Total Plate Count" (ALT) in all meatball stall are ineligible. The conclusion of this study is hygiene sanitary processing meatballs in five traders still do not qualified, as well as in 5 samples are negative Salmonella sp and "Total Plate Count" of five stalls are not eligible. Suggestion can be given that shop owners should improve hygiene sanitation and food processing uses 3 sinks to wash kitchen tools in order to reduce the number of bacteria in the processing tool.
\end{abstract}

Key words : Hygiene sanitary food processing, Salmonella sp

\section{PENDAHULUAN}

Sebagai ukuran kesehatan masyarakat, pengawasan dan inspeksi makanan berperan sangat penting dalam upaya pencegahan penyakit bawaan makanan, gangguan kesehatan, kesengsaraan, dan kematian. Seiring berkembangnya zaman, saat ini banyak orang yang tidak sempat menyiapkan sendiri makanan yang akan dikonsumsi. Banyak di antara

1) Email : beningratri78@yahoo.co.id

2) Email : aseptatagunawan@yahoo.co.id mereka yang bergantung pada pelayanan jasa penyedia makanan untuk memenuhi kebutuhan makanannya. Kenyataan ini mendorong semakin berkembangnya warung makan, restoran, catering, kafe, bahkan warung tenda, dan lesehan. Tempattempat seperti itu akan semakin memiliki tanggung jawab yang besar dalam menyediakan makanan yang 
berkualitas, yaitu enak, kompetitif dalam harga, dan aman untuk dikonsumsi.

Menurut data dari BPOM RI pada bulan April sampai Juni 2015 terdapat 56 berita insiden keracunan yang terjadi di berbagai wilayah Indonesia. Kasus keracunan makanan menduduki urutan penyebab kejadian luar biasa (KLB) kedua di Jawa Tengah yang menyerang 63 desa di 53 kecamatan dengan penderita sebanyak 1.298 orang dengan CFR sebesar 0,46\%. Pada tahun 2004, dari 35 kabupaten/kota yang ada di Jawa Tengah terdapat 22 kabupaten/kota yang melaporkan adanya KLB keracunan makanan. Kota Semarang, Kabupaten Boyolali, Cilacap, Banyumas, dan Purbalingga merupakan wilayah yang banyak ditemukan KLB keracunan makanan.

Sokaraja merupakan daerah kuliner di Kabupaten Banyumas salah satu makanannya yaitu bakso. Saat ini bakso menjadi makanan yang digemari oleh masyarakat. Konsumsi bakso merupakan salah satu kebutuhan terhadap protein hewani. Bakso dapat dijumpai di sepanjang Jalan Jenderal Sudirman yang memang menjadi jalan utama bagi kendaraan dari luar kota masuk ke dalam wilayah Sokaraja atau yang ingin ke Purwokerto. Tujuan penelitian ini adalah untuk mendeskripsikan hygiene sanitasi pengolahan makanan dan kandungan bakteri Salmonella sp pada bakso yang dijual di Jl. Jenderal Sudirman Sokaraja Tahun 2016.

\section{BAHAN DAN METODE}

Penelitian ini dilaksanakan di Jl. Jenderal Sudirman Sokaraja Kabupaten Banyumas, kemudian diperiksa di Laboratorium Kampus VII Poltekkes Kemenkes Semarang..

Subyek dalam penelitian ini adalah hygiene sanitasi pengolahan makanan dan kandungan Salmonella sp pada bakso yang dijual oleh 5 pedagang di Jl. Jenderal Sudirman Sokaraja. Jenis data yang dikumpulkan meliputi data umum berupa gambaran umum pedagang, nama penjamah, jumlah pedagang bakso, dan jumlah bakso yang terjual di Jl. Jenderal Sudirman Sokaraja dan data khusus berupa Salmonella sp pada bakso, personal hygiene dan sanitasi pengolahan makanan. Sumber data adalah data primer hasil observasi menggunakan checklist di pedagang bakso Jl. Jenderal Sudirman Sokaraja meliputi penjamah, bahan makanan, sanitasi alat, tempat pengolahan, pemilihan bahan makanan, penyimpanan bahan makanan, pengolahan bakso, pengangkutan bakso, penyimpanan bakso dan penyajian bakso dan kandungan Salmonella sp pada bakso dan data sekunder berupa data nama pemilik rumah makan, alamat, jumlah penjamah, jumlah karyawan dan nomor izin usaha. Cara pengumpulan data berupa observasi dan pemeriksaan laboratorium

Analisis data menggunakan analisis deskriptif. Analisis terhadap data yang ada pada tabel lalu membandingkan hasil di lapangan dengan Peraturan Kepala Badan Pengawas Obat dan Makanan
Republik Indonesia Nomor HK.00.06.1.52.4011 tentang Penetapan Batas Maksimum Cemaran Mikroba dan Kimia dalam Makanan, bakteri Salmonella sp pada bakso adalah negatif/25 gram.

\section{HASIL DAN PEMBAHASAN}

a. Hygiene sanitasi makanan bakso di Jl. Jenderal Sudirman Sokaraja

Berdasarkan hasil penelitian ini memberikan gambaran tentang keadaan hygiene sanitasi pengolahan bakso mulai dari pemilihan bahan makanan sampai penyajian makanan dan hasil pemeriksaan Salmonella sp pada bakso dan ALT alat makan di 5 pedagang bakso Jl. Jenderal Sudirman Sokaraja Tahun 2016, yang dapat dijelaskan sebagai berikut:

Tabel 1 Personal Hygiene dan perilaku penjamah 5 pedagang bakso di $\mathrm{Jl}$. Jenderal Sudirman Sokaraja Tahun 2016

\begin{tabular}{|c|c|c|c|c|}
\hline No & Variabel & Kategori & $\sum$ & $\%$ \\
\hline \multirow[t]{2}{*}{1.} & \multirow{2}{*}{$\begin{array}{l}\text { Personal } \\
\text { hygiene }\end{array}$} & Memenuhi syarat & 0 & $0 \%$ \\
\hline & & memenuhi & 5 & $100 \%$ \\
\hline \multirow[t]{2}{*}{2.} & \multirow{2}{*}{$\begin{array}{l}\text { Perilaku } \\
\text { penjamah }\end{array}$} & Memenuhi syarat & 1 & $20 \%$ \\
\hline & & $\begin{array}{l}\text { Tidak } \\
\text { syarat }\end{array}$ & 4 & $80 \%$ \\
\hline
\end{tabular}

Berdasarkan tabel diatas personal hygiene dari 5 pedagang tersebut tidak memenuhi syarat semua karena masih terdapat komponen yang belum memenuhi syarat yaitu tidak memakai sarung tangan, penjamah tidak menggunakan celemek dan penjamah tidak menggunakan alas kaki khusus dapur. Para pemilik rumah makan sebaiknya menempel poster tentang cuci tangan yang benar dan menyediakan alat pelindung diri (APD) agar personal hygiene penjamah sesuai dengan peraturan yang ada. Alat pelindung diri tersebut seperti penutup kepala, pakaian kerja, sarung tangan, celemek, dan alas kaki dapur. Pengetahuan para penjamah perlu ditingkatkan. Hal tersebut dapat dilakukan dengan cara penyuluhan baik dari puskesmas maupun dinas kesehatan setempat dengan cara pemasangan leaflet tentang perilaku penjamah yang benar.

Tabel 2 Pemilihan Daging Sapi 5 pedagang bakso di Jl. Jenderal Sudirman Sokaraja Tahun 2016

\begin{tabular}{lllll}
\hline No & Variabel & \multicolumn{1}{c}{ Kategori } & $\sum$ & $\mathbf{\%}$ \\
\hline 1. & $\begin{array}{l}\text { Pemilihan } \\
\text { daging sapi }\end{array}$ & $\begin{array}{l}\text { Memenuhi } \\
\text { syarat }\end{array}$ & 5 & $100 \%$ \\
\cline { 3 - 5 } & & $\begin{array}{l}\text { Tidak } \\
\text { memenuhi } \\
\text { syarat }\end{array}$ & 0 & $0 \%$ \\
& & & \\
\hline
\end{tabular}

Berdasarkan tabel diatas pemilihan daging sapi 5 pedagang bakso yang ada semuanya 
memenuhi syarat yaitu daging warna merah segar, serat halus, dan lemak lunak warna kuning. Jika pemilihan daging sapi yang salah maka daging tersebut sudah lama atau mengalami pembusukan sehingga akan menghasilkan zat yang bersifat racun. Sebaiknya pedagang tetap memperhatikan ciri-ciri daging yang baik.

Tabel 3 Kualitas Fisik Bahan Makanan 5 pedagang bakso di Jl. Jenderal Sudirman Sokaraja Tahun 2016

\begin{tabular}{|c|c|c|c|c|}
\hline No & Variabel & Kategori & $\sum$ & $\%$ \\
\hline \multirow[t]{2}{*}{1.} & \multirow[t]{2}{*}{ Tepung } & Memenuhi syarat & 5 & $100 \%$ \\
\hline & & $\begin{array}{l}\text { Tidak memenuhi } \\
\text { syarat }\end{array}$ & 0 & $0 \%$ \\
\hline \multirow[t]{2}{*}{2.} & \multirow[t]{2}{*}{ Sayuran } & Memenuhi syarat & 5 & $100 \%$ \\
\hline & & $\begin{array}{l}\text { Tidak memenuhi } \\
\text { syarat }\end{array}$ & 0 & $0 \%$ \\
\hline \multirow[t]{2}{*}{3.} & \multirow[t]{2}{*}{ Mie } & Memenuhi syarat & 5 & $100 \%$ \\
\hline & & $\begin{array}{ll}\text { Tidak memenuhi } \\
\text { syarat }\end{array}$ & 0 & $0 \%$ \\
\hline \multirow[t]{2}{*}{4.} & \multirow[t]{2}{*}{ Bihun } & Memenuhi syarat & 5 & $100 \%$ \\
\hline & & $\begin{array}{ll}\text { Tidak memenuhi } \\
\text { syarat }\end{array}$ & 0 & $0 \%$ \\
\hline \multirow[t]{2}{*}{5.} & \multirow[t]{2}{*}{ Bumbu } & Memenuhi syarat & 5 & $100 \%$ \\
\hline & & $\begin{array}{l}\text { Tidak memenuhi } \\
\text { syarat }\end{array}$ & 0 & $0 \%$ \\
\hline \multirow[t]{2}{*}{6.} & \multirow{2}{*}{$\begin{array}{l}\text { Makanan } \\
\text { olahan } \\
\text { pabrik }\end{array}$} & Memenuhi syarat & 5 & $100 \%$ \\
\hline & & $\begin{array}{l}\text { Tidak memenuhi } \\
\text { syarat }\end{array}$ & 0 & $0 \%$ \\
\hline
\end{tabular}

Berdasarkan tabel diatas cara pemilihan bahan makanan dari 5 pedagang tersebut memenuhi syarat semua. Hal-hal yang memenuhi syarat mulai dari tepung, sayuran, mie, bihun, bumbu dan makanan olahan pabrik. Untuk tetap menjaga kualitas bakso yang disajikan sebaiknya pedagang tetap memperhatikan keadaan bahan makanan yang dipakai sehingga tidak menimbulkan gangguan penyakit dan membahayakan kesehatan pembeli.

Tabel 4 Sanitasi Alat 5 pedagang bakso di Jl. Jenderal Sudirman Sokaraja Tahun 2016

\begin{tabular}{|c|c|c|c|c|}
\hline No & Variabel & Kategori & $\sum$ & $\%$ \\
\hline \multirow[t]{2}{*}{1.} & Sanitasi & Memenuhi syarat & 0 & $0 \%$ \\
\hline & Alat & $\begin{array}{l}\text { Tidak memenuhi } \\
\text { syarat }\end{array}$ & 5 & $100 \%$ \\
\hline
\end{tabular}

Berdasarkan tabel diatas sanitasi alat dari 5 pedagang tersebut semuanya tidak memenuhi syarat, hal ini disebabkan karena pada komponen cangkir, mangkok, gelas dan sejenisnya cara penyimpanannya tidak dibalik khususnya pada mangkok yang semuanya hanya ditumpuk.

Tabel 5 Hasil Pemeriksaan Angka Lempeng Total (ALT) pada alat makan 5 pedagang bakso di Jl. Jenderal Sudirman Sokaraja Tahun 2016

\begin{tabular}{|c|c|c|c|c|c|}
\hline \multirow[b]{2}{*}{ No } & \multirow[b]{2}{*}{ Nama } & \multirow{2}{*}{$\begin{array}{c}\text { Hasil } \\
\text { pemerik } \\
\text { saan } \\
(\text { Koloni/ } \\
\left.\mathbf{c m}^{2}\right) \\
\end{array}$} & \multirow{2}{*}{$\begin{array}{c}\text { Standar } \\
* \\
\left(\begin{array}{c}\text { Koloni } \\
\left.\mathrm{cm}^{2}\right)\end{array}\right.\end{array}$} & \multicolumn{2}{|c|}{ Keterangan } \\
\hline & & & & MS & TMS \\
\hline 1. & Mr. A & 3.100 & \multirow{7}{*}{100} & 0 & 1 \\
\hline 2. & Mr. B & 11.200 & & 0 & 1 \\
\hline 3. & Mr. C & 14.600 & & 0 & 1 \\
\hline 4. & Mrs. D & 5.400 & & 0 & 1 \\
\hline 5. & Mrs. E & 4.500 & & 0 & 1 \\
\hline & Jumlah & & & 0 & 5 \\
\hline & $\%$ & & & $0 \%$ & $100 \%$ \\
\hline
\end{tabular}

Berdasarkan tabel diatas masih ada warung yang tidak mempunyai rak-rak penyimpanan peralatan serta pemeriksaan ALT pada alat makan di 5 pedagang tersebut semuanya lebih dari 100 koloni $/ \mathrm{cm}^{2}$. Untuk menurunkan ALT pada alat makan dapat dilakukan pencucian peralatan dengan benar dan perlu dilakukan penyuluhan oleh petugas puskesmas atau dinas kesehatan setempat terhadap pedagang mengenai pencucian peralatan menggunakan 3 bak yang benar, serta apabila peralatan yang sudah tidak layak pakai seperti berkarat dan retak sebaiknya diganti dengan peralatan baru.

Tabel 6 Sanitasi Tempat Pengolahan 5 pedagang bakso di Jl. Jenderal Sudirman Sokaraja Tahun 2016

\begin{tabular}{|c|c|c|c|}
\hline Variabel & Kategori & $\sum$ & $\%$ \\
\hline \multirow[t]{2}{*}{ 1. Lantai } & Memenuhi syarat & 5 & $100 \%$ \\
\hline & $\begin{array}{ll}\text { Tidak memenuhi } \\
\text { syarat }\end{array}$ & 0 & $0 \%$ \\
\hline \multirow[t]{2}{*}{ 2. Dinding } & Memenuhi syarat & 5 & $100 \%$ \\
\hline & $\begin{array}{ll}\text { Tidak memenuhi } \\
\text { syarat }\end{array}$ & 0 & $0 \%$ \\
\hline \multirow[t]{2}{*}{ 3. Langit-langit } & Memenuhi syarat & 3 & $60 \%$ \\
\hline & $\begin{array}{ll}\text { Tidak memenuhi } \\
\text { syarat }\end{array}$ & 2 & $40 \%$ \\
\hline \multirow[t]{2}{*}{ 4. Pencahayaan } & Memenuhi syarat & 2 & $40 \%$ \\
\hline & memenuhi & 3 & $60 \%$ \\
\hline \multirow[t]{2}{*}{ 5. Ventilasi } & Memenuhi syarat & 2 & $40 \%$ \\
\hline & memenuhi & 3 & $60 \%$ \\
\hline \multirow{2}{*}{$\begin{array}{l}\text { 6. } \\
\text { asap }\end{array}$} & Memenuhi syarat & 0 & $0 \%$ \\
\hline & $\begin{array}{l}\text { Tidak memenuhi } \\
\text { syarat }\end{array}$ & 5 & $100 \%$ \\
\hline \multirow{2}{*}{$\begin{array}{l}\text { 7. Tempat } \\
\text { sampah }\end{array}$} & Memenuhi syarat & 0 & $0 \%$ \\
\hline & memenuhi & 5 & $100 \%$ \\
\hline \multirow[t]{2}{*}{ 8. SPAL } & Memenuhi syarat & 0 & $0 \%$ \\
\hline & memenuhi & 5 & $100 \%$ \\
\hline 9. Tempat cuci & Memenuhi syarat & 4 & $80 \%$ \\
\hline
\end{tabular}




\begin{tabular}{|c|c|}
\hline & $\begin{array}{lllll}\text { tangan dan } & \text { Tidak } & \text { memenuhi } & 1 & 20 \% \\
\text { alat dapur } & \text { syarat } & & & \end{array}$ \\
\hline \multirow[t]{2}{*}{10} & Pengendalian Memenuhi syarat \\
\hline & 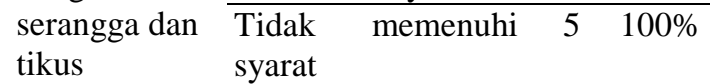 \\
\hline & $\begin{array}{l}\text { Berdasarkan tabel diatas sanitasi tempat } \\
\text { pengolahan mulai dari lantai, dinding, langit- } \\
\text { langit, pencahayaan, ventilasi, cerobong asap, } \\
\text { tempat sampah, saluran air limbah, tempat cuci } \\
\text { tangan dan alat-alat dapur serta pengendalian } \\
\text { serangga dan tikus dari } 5 \text { pedagang masih ada } \\
\text { yang tidak memenuhi syarat. Pengetahuan dan } \\
\text { perilaku pedagang dan penjamah terhadap syarat } \\
\text { tempat pengolahan makanan perlu ditingkatkan } \\
\text { agar mereka mengetahui perilaku yang baik } \\
\text { dalam mengolah makanan. Hal ini dapat } \\
\text { dilakukan dengan cara penyuluhan oleh } \\
\text { puskesmas atau dinas kesehatan setempat. Aspek } \\
\text { yang belum memenuhi syarat sebaiknya } \\
\text { diperbaiki seperti lantai disapu sebelum dan } \\
\text { sesudah mengolah makanan, rajin membersihkan } \\
\text { langit-langit satu minggu sekali, jika ada langit- } \\
\text { langit yang berlubang segera diperbaiki, } \\
\text { memberi tutup pada tempat sampah, melakukan } \\
\text { pengendalian serangga dan tikus secara berkala. }\end{array}$ \\
\hline
\end{tabular}

Tabel 7 Pemilihan bahan makanan 5 pedagang bakso di Jl. Jenderal Sudirman Sokaraja Tahun 2016

\begin{tabular}{lllll}
\hline No & Variabel & \multicolumn{1}{c}{ Kategori } & $\sum$ & $\mathbf{\%}$ \\
\hline 1. & Pemilihan & Memenuhi syarat & 5 & $100 \%$ \\
\cline { 3 - 5 } & $\begin{array}{l}\text { bahan } \\
\text { makanan }\end{array}$ & $\begin{array}{l}\text { Tidak memenuhi } \\
\text { syarat }\end{array}$ & 0 & $0 \%$ \\
\hline
\end{tabular}

Berdasarkan tabel diatas pemilihan bahan makanan 5 pedagang bakso memenuhi syarat semua. Hal-hal yang memenuhi syarat antara lain kondisi fisik bahan makanan dalam keadaan baik, bahan makanan berasal dari sumber resmi, dan bahan makanan kemasan tidak ada tandatanda kerusakan dan terdaftar pada Depkes RI. Cara pemilihan bahan makanan sudah baik dan memenuhi syarat. Meskipun demikian, tetap perlu memperhatikan cara pemilihan bahan makanan yang benar agar kualitas bahan makanan tetap terjaga.

Tabel 8 Penyimpanan bahan makanan 5 pedagang bakso di Jl. Jenderal Sudirman Sokaraja Tahun 2016

\begin{tabular}{ccccc}
\hline No & Variabel & Kategori & $\sum$ & $\mathbf{\%}$ \\
\hline 1. & $\begin{array}{l}\text { Penyimpanan } \\
\text { bahan } \\
\text { makanan }\end{array}$ & \begin{tabular}{l} 
Memenuhi syarat \\
\cline { 2 - 5 }
\end{tabular} & $\begin{array}{l}\text { Tidak memenuhi } \\
\text { syarat }\end{array}$ & $60 \%$ \\
\hline & Berdasarkan & tabel diatas penyimpanan
\end{tabular}

bahan makanan pedagang bakso yang memenuhi syarat ada 3 warung yaitu warung Mr. A, B, dan Mrs. E. Hal-hal yang memenuhi syarat meliputi tempat penyimpanan yang bersih, penempatannya terpisah dengan makanan jadi, bebas dari serangga dan tikus, daging sapi yang disimpan di lemari es suhunya $-5^{\circ} \mathrm{C}$ sampai $0^{\circ} \mathrm{C}$ sedangkan warung Mr. C dan Mrs. D tidak memenuhi syarat karena daging sapi yang disimpan di lemari es suhunya dengan suhu $5^{\circ} \mathrm{C}$.

Sebaiknya para pedagang memperhatikan tempat dan suhu penyimpanan agar kualitas daging tetap terjaga serta tetap memelihara tempat penyimpanan bahan makanan agar bahan makanan tersebut tidak terkontaminasi.

Tabel 9 Pengolahan Bakso 5 pedagang bakso di Jl. Jenderal Sudirman Sokaraja Tahun 2016

\begin{tabular}{lllll}
\hline No & Variabel & \multicolumn{1}{c}{ Kategori } & $\sum$ & \% \\
\hline 1. & Tenaga & Memenuhi syarat & 2 & $40 \%$ \\
& pengolah & Tidak memenuhi & 3 & $60 \%$ \\
2. & $\begin{array}{l}\text { Cara } \\
\text { pengolahat }\end{array}$ & $\begin{array}{l}\text { Memenuhi syarat } \\
\text { Tidak memenuhi } \\
\text { syarat }\end{array}$ & 5 & $100 \%$ \\
\hline
\end{tabular}

Berdasarkan tabel diatas pengolahan bakso dari 5 pedagang yang memenuhi syarat baik dari tenaga pengolah dan cara pengolahan yaitu warung Mr. A dan Mrs. E. Hal-hal yang memenuhi syarat meliputi pengambilan makanan jadi menggunakan alat yang khusus, menggunakan peralatan dengan benar, bahan makanan diolah dengan memperhatikan kebersihan, bakso direbus sampai naik ke permukaan, sayuran di cuci bersih menggunakan air bersih yang mengalir, serta mie dan bihun direbus/disiram dengan air panas. Sedangkan warung yang lain masih ada yang tidak memenuhi syarat dari tenaga pengolahnya karena pada pengambilan makanan jadi tidak menggunakan alat yang khusus.

Pada pengolahan bakso tersebut sebaiknya pemilik warung makan menyediakan dan menggunakan alat yang sesuai untuk mengambil setiap jenis makanan seperti menggunakan alat penjempit makanan atau memakai sarung tangan plastik sehingga bisa digunakan satu kali pakai.

Tabel 10Pengangkutan Bakso 5 pedagang bakso di Jl. Jenderal Sudirman Sokaraja Tahun 2016

\begin{tabular}{|c|c|c|c|c|}
\hline No & Variabel & Kategori & $\sum$ & $\%$ \\
\hline \multirow[t]{2}{*}{1.} & Pengang & Memenuhi syarat & 0 & $0 \%$ \\
\hline & $\begin{array}{l}\text { kutan } \\
\text { bakso }\end{array}$ & memenuhi & 5 & $100 \%$ \\
\hline
\end{tabular}

Berdasarkan tabel diatas pengangkutan bakso pada 5 pedagang semuanya masih tidak memenuhi syarat karena pada proses pengangkutan bakso tidak menggunakan wadah yang tertutup.

Makanan yang telah diolah dengan cara hygienis akan tetapi cara pengangkutannya tidak baik akan menimbulkan kontaminasi terhadap makanan tersebut sehingga perlu diperhatikan cara pengangkutan makanan yang benar menurut 
peraturan yang ada. Untuk itu, pemilik rumah makan sebaiknya menyediakan wadah untuk masing-masing jenis makanan, isi makanan jangan terlampau penuh sehingga tidak tumpah, dan wadah harus mempunyai tutup agar menghindari kontaminasi terhadap makanan tersebut dan dapat menjaga kualitas makanan.

Tabel 11Penyimpanan Bakso 5 pedagang bakso di Jl. Jenderal Sudirman Sokaraja Tahun 2016

\begin{tabular}{lllll}
\hline No & Variabel & \multicolumn{1}{c}{ Kategori } & $\sum$ & \multicolumn{1}{c}{$\%$} \\
\hline 1. & Penyimpan & Memenuhi syarat & 5 & $100 \%$ \\
& an bakso & $\begin{array}{l}\text { Tidak memenuhi } \\
\text { syarat }\end{array}$ & $0 \%$ \\
& & $0 \%$ \\
\hline
\end{tabular}

Berdasarkan tabel diatas penyimpanan bakso di 5 pedagang semuanya memenuhi syarat seperti terlindung dari debu, terlindung dari serangga, cara penyimpanannya tertutup, dan disimpan dilemari pendingin. Oleh karena itu, pemilik rumah makan tetap memperhatikan tempat dan cara penyimpanan makanan agar tidak terkontaminasi oleh makanan atau lingkungan yang ada.

Tabel 12Penyajian Bakso 5 pedagang bakso di Jl. Jenderal Sudirman Sokaraja Tahun 2016

\begin{tabular}{|c|c|c|c|c|}
\hline No & Variabel & Kategori & $\sum$ & $\%$ \\
\hline \multirow[t]{2}{*}{1.} & Penyajian & Memenuhi syarat & 3 & $60 \%$ \\
\hline & bakso & $\begin{array}{l}\text { Tidak memenuhi } \\
\text { syarat }\end{array}$ & 2 & $40 \%$ \\
\hline
\end{tabular}

pada 5 pedagang yang memenuhi syarat ada 3 warung yaitu warung Mr. A, Mrs. D, dan Mrs. E sedangkan yang tidak memenuhi syarat warung Mr. B dan Mr. C karena pada item meja dimana makanan disajikan tidak tertutup dengan kain putih atau plastik berwana menarik dan tempat penyajiannya tidak bersih.

Makanan yang sudah diolah dan disajikan dengan cara yang hygienis akan tetapi jika cara penyajiannya tidak dilakukan dengan baik sesuai peraturan yang ada maka akan tercemar juga. Sebaiknya penjamah lebih memperhatikan cara penyajian yang benar sesuai dengan peraturan yang ada seperti membawa makanan dengan cara tertutup, nampan harus sering dibersihkan, tempat kecap, saus dll sering dibersihkan dan dijaga kebersihan mulut-mulutnya. Kesadaran penjamah juga penting diperhatikan dalam penyajian makanan agar tidak terkontaminasi. Para pemilik rumah makan sebaiknya menggunakan kain atau plastik untuk menutupi meja agar mudah dibersihkan, dan selalu membersihkan serta menjaga tempat penyajian agar selalu bersih.

\section{b. Kandungan Salmonella sp Pada Bakso}

Pemeriksaan Sampel Bakso yang dilakukan pada tanggal 13 Juni -19 Juni 2016 di Laboratorium Kampus 7 Jurusan Kesehatan Lingkungan Purwokerto. Sampel bakso yang diambil sebanyak 5 sampel semuanya negatif (tidak ada Salmonella sp). Berikut hasil pemeriksaan secara kuantitatif di laboratorium dan diperoleh hasil yang dapat dilihat pada tabel 13.

Tabel 13Hasil Pemeriksaan Salmonella sp Pada Bakso yang dijual oleh 5 pedagang bakso di Jl. Jenderal Sudirman Sokaraja Tahun 2016

\begin{tabular}{cclc}
\hline No & $\begin{array}{c}\text { Kode } \\
\text { sampel }\end{array}$ & $\begin{array}{c}\text { Hasil } \\
\text { Pemeriksaan }\end{array}$ & $\begin{array}{c}\text { Standar } \\
* \text { ) }\end{array}$ \\
\hline 1. & Mr. A & Negatif & \\
2. & Mr. B & Negatif & Negatif/ \\
3. & Mr. C & Negatif & 25gr \\
4. & Mrs. D & Negatif & \\
5. & Mrs. E & Negatif & \\
\hline *) & Peraturan Badan Pengawas Obat dan \\
\multicolumn{4}{c}{ Makanan No. HK.00.06.1.52.4011 Tahun } \\
2009 tentang Batas Maksimum Cemaran \\
Mikroba dan Kimia dalam Makanan adalah \\
Negatif/25 gram.
\end{tabular}

Berdasarkan tabel diatas dapat diketahui bahwa 5 sampel bakso yang diambil dari warung Mr. A, Mr. B, Mr. C, Mrs. D dan Mrs. E dan diteliti di laboratorium Kampus 7 Jurusan Kesehatan Lingkungan Purwokerto negatif Salmonella sp.

Berdasarkan pemeriksaan yang dilakukan hasilnya baik, semuanya negatif Salmonella $s p$, meskipun demikian tetap perlu adanya penyuluhan dari puskesmas atau dinas kesehatan setempat terhadap penjamah makanan agar mereka dapat mengolah makanan dengan baik. Selain itu agar mereka dapat mengetahui kondisi yang dapat menyebabkan adanya Salmonella $s p$ yang tumbuh dan berkembang. Pengolahan yang benar dapat mencegah terjadinya bahaya bagi konsumennya.

\section{KESIMPULAN}

1. Hygiene sanitasi makanan bakso di Jl. Jenderal Sudirman Sokaraja

a. Penjamah

Berdasarkan hasil observasi yang dilakukan oleh peneliti di 5 lokasi penelitian (A-E), aspek penjamah mulai dari personal hygiene, perilaku penjamah, dan sertifikat hygiene sanitasi kelima warung tersebut dikategorikan tidak memenuhi syarat.

b. Bahan makanan

Berdasarkan pengamatan peneliti di 5 lokasi penelitian (A-E), bahan makanan yang digunakan seperti daging sapi, tepung, bihun, mie, bumbu dan makanan olahan 
pabrik dikategorikan memenuhi syarat semua pada 5 pedagang tersebut.

c. Sanitasi alat

Sanitasi alat dari 5 pedagang tersebut semuanya tidak memenuhi syarat, hal ini disebabkan karena pada komponen cangkir, mangkok, gelas dan sejenisnya cara penyimpanannya tidak dibalik khususnya pada mangkok yang semuanya hanya ditumpuk, masih ada warung yang tidak mempunyai rak-rak penyimpanan peralatan serta pemeriksaan ALT pada alat makan yang tidak memenuhi syarat.

d. Sanitasi tempat pengolahan

Berdasarkan hasil pengamatan peneliti di 5 lokasi penelitian (A-E), sanitasi tempat pengolahan mulai dari lantai, dinding, langit-langit, pencahayaan, ventilasi, cerobong asap, tempat sampah, saluran air limbah, tempat cuci tangan dan alat-alat dapur serta pengendalian serangga dan tikus dikategorikan tidak memenuhi syarat semua pada 5 pedagang tersebut.

e. Pemilihan bahan makanan

Berdasarkan hasil pengamatan yang telah dilakukan menggunakan checklist dalam pemilihan bahan makanan diperoleh hasil memenuhi syarat untuk kelima pedagang bakso tersebut.

f. Penyimpanan bahan makanan

Berdasarkan hasil pengamatan yang telah dilakukan oleh peneliti menggunakan checklist dalam penyimpanan bahan makanan diperoleh hasil tidak memenuhi syarat untuk kelima pedagang bakso tersebut.

g. Pengolahan Bakso

Berdasarkan hasil pengamatan yang telah dilakukan oleh peneliti menggunakan checklist di 5 lokasi penelitian (A-E) diperoleh hasil tidak memenuhi syarat semua dalam aspek pengolahan bakso di 5 pedagang yang ada.

h. Pengangkutan bakso

Berdasarkan hasil pengamatan yang telah dilakukan menggunakan checklist diperoleh hasil Mr. A, Mr. B, Mr. C, Mrs. D dan Mrs. E tidak memenuhi syarat. Hal tersebut dikarenakan pada proses pengangkutan bakso tidak menggunakan wadah yang tertutup.

i. Penyimpanan bakso

Berdasarkan hasil pengamatan yang telah dilakukan menggunakan checklist diperoleh hasil Mr. A, Mr. B, Mr. C, Mrs. D dan Mrs. E semuanya memenuhi syarat seperti terlindung dari debu, terlindung dari serangga, cara penyimpanannya tertutup, dan disimpan dilemari pendingin.

j. Penyajian bakso
Berdasarkan hasil pengamatan yang telah dilakukan oleh peneliti menggunakan checklist di 5 lokasi penelitian (A-E) diperoleh hasil tidak memenuhi syarat semua dalam aspek penyajian bakso di 5 pedagang yang ada.

2. Keberadaan Salmonella sp Pada Bakso

Hasil pemeriksaan pada sampel bakso yang diambil dari 5 pedagang semuanya negatif (tidak ada Salmonella).

Saran untuk konsumen tetap waspada dalam memilih makanan yang di jual dipinggir jalan, bagi pedagang tetap menjaga hygiene sanitasi pengolahan makanan agar mengolah makanan dengan benar, dan untuk dinas kesehatan sebaiknya melakukan penyuluhan secara rutin untuk mengawasi hygiene sanitasi warung makan yang ada di wilayah kerjanya.

\section{Ucapan Terimakasih}

Terima kasih disampaikan kepada pedagang bakso di Jl. Jenderal Sudirman Sokaraja, Jurusan Kesehatan Lingkungan, dosen pembimbing KTI Politeknik Kesehatan Kemenkes Semarang serta pihak-pihak yang terkait sehingga penelitian ini dapat terlaksana dengan lancar.

\section{Daftar Pustaka}

Badan POM, 2015, "Sentra Informasi Keracunan Makanan Nasional". (Online). Tersedia:http://ik.pom.go.id/v2015/. ） (1 November 2015)

Depkes RI, 2000, Prinsip-Prinsip Hygiene Sanitasi Makanan, Jakarta: Departemen Kesehatan RI

$\begin{array}{llr}\text { No.1098/MENKES/SK/VII/2003 } & \text { RI } \\ \text { Pentang } \\ \text { Makanatan Dan Restoran, Jakarta }\end{array}$

$\begin{array}{lrr}\text { 2003, KEPMENKES } & \text { RI } \\ \text { No.715/MENKES/SK/V/2003 tentang } \\ \begin{array}{l}\text { Persyaratan } \\ \text { Jakarta }\end{array}\end{array}$
2009, Rencana Pembangunan Jangka Panjang Bidang Kesehatan 2005-2025, Jakarta: Depkes RI

2010, Kumpulan Modul Kursus Hygiene Sanitasi Makanan dan Minuman, Jakarta: Direktorat Jenderal PP \& PL 2011, Peraturan Meteri Kesehatan RI No. 1096 tahun 2011 tentang Higiene Sanitasi Jasaboga, Jakarta: Departemen Kesehatan RI 
Dinas Kesehatan Provinsi Jawa Tengah, 2004, "Bab IV : Pencapaian program kesehatan menuju jawa tengah sehat”, Jurnal Dinas Kesehatan Provinsi Jawa Tengah,http://www.dinkesjatengprov.go.id/d okumen/profil/profile2004/bab4.htm, 25 November 2015

E.Jawetz dkk, 1984, Mikrobiologi Untuk Profesi Kesehatan Edisi 16, Jakarta: Buku Kedokteran EGC

Hiasinta A Purnawijayanti, 2000, Mi Sehat Cara Pembuatan, Resep-Resep Olahan dan Peluang Bisnis, Yogyakarta: Kanisius

2001, Sanitasi Hygiene dan Keselamatan Kerja Dalam Pengolahan Makanan, Yogyakarta: Penerbit Kanisius

M.J Pelczar Jr dan E.C.S Chan, 1988, Dasar-Dasar Mikrobiologi, Jakarta: Universitas Indonesia

Krisna, 2011, “Usai Makan Bakso Warga Keracunan”, (Online). Tersedia:http://www.tribunnews.com/region al/2011/03/06/usai-makan-bakso-wargakeracunan (1 November 2015)

Lukman Saksono, 1986, Pengantar Sanitasi Makanan, Bandung: Alumni

Made Astawan MS, 1999, Membuat Mi dan Bihun, Depok: Penebar Swadaya

Peraturan Kepala Badan Pengawas Obat dan Makanan Republik Indonesia Nomor HK.00.06.1.52.4011 tentang Penetapan Batas Maksimum Cemaran Mikroba dan Kimia dalam Makanan, Jakarta
Riyanti GW, 2007, Muslimah Cerdas dan Kreatif, Jakarta: Qultum Media

SOP Praktikum Mata Kuliah PMM-B, 2015, Uji Alat Makan, Politeknik Kesehatan Kemenkes Semarang Jurusan Kesehatan Lingkungan Purwokerto

SOP Praktikum Mata Kuliah PMM-A, 2015, Uji Kandungan Salmonella sp, Politeknik Kesehatan Kemenkes Semarang Jurusan Kesehatan Lingkungan Purwokerto

SOP Praktikum Mata Kuliah Mikrobiologi, 2014, Pengambilan Sampel Makanan, Politeknik Kesehatan Kemenkes Semarang Jurusan Kesehatan Lingkungan Purwokerto

Standar Nasional Indonesia 01-3818-1995 tentang Baso Daging

Standar Nasional Indonesia 7388:2009 tentang Batas Maksimum Cemaran Mikroba dalam Pangan, Jakarta

Tri Cahyono, 2004, Pedoman Penulisan Proposal dan Karya Tulis Ilmiah/Skripsi Edisi revisi ketiga, Purwokerto, Kementerian Kesehatan RI Politeknik Kesehatan Depkes Semarang Jurusan Kesehatan Lingkungan

WHO, 2002, Buku Penyakit Bawaan Makanan Fokus Pendidikan Kesehatan, Jakarta: Buku Kedokteran EGC

Yusta Akhnisia, 2008, Studi Kandungan Bakteri Salmonella sp pada Daging Sapi Segar Yang Dijual di Pasar Kecamatan Kutoarjo Kabupaten Purworejo Tahun 2008, Karya Tulis Ilmiah pada Jurusan Kesehatan Lingkungan Poltekkes Kemenkes Semarang 